\title{
METAMORPHIC DIFFERENTIATION IN SOME BIOTITE SCHISTS FROM NORTH-EAST ANTRIM, IRELAND
}

\author{
V. MATHAVAN \\ Department of Geology, University of Peradeniya, Peradeniya.
}

(Date of receipt: 18 November 1986)

(Date of acceptance: 23. February 1987)

\begin{abstract}
Biotite in some biotite grade pelitic rocks from north-east Antrim, Ireland, is concentrated along $\mathrm{S}_{2}$ cleavage zones and is absent, or present only in small amounts, in areas between the cleavage zones. Thus, the $\mathrm{S}_{2}$ cleavage zones form biotite-rich domains, while the intervening areas form biotite-poor domains in the rocks. It is shown that the various models proposed to explain metamorphic differentiation, involving passive concentration of more dense, less soluble phases by solution and selective removal of more soluble phases, cannot be used to account-for the differentiated feature observed in the studied rocks. To explain the segregation and the mechanism of metamorphic differentiation, it is suggested that biotite had preferentially nucleated and grown in the $\mathrm{S}_{2}$ cleavage zones.
\end{abstract}

\section{Introduction}

The term metamophic differentiation denotes collectively the various processes by which contrasted mineral assemblages develop from a rock in which the minerals are more or less uniformly distributed. It is also used in a wider sense to include growth of porphyroblasts and reaction between compositionally contrasting adjacent layers. ${ }^{2.3}$ The differentiation of a metamorphic rock into mineralogical and/or chemically different portions is contrary to the generally accepted concept that metamorphism usually tends to obliterate compositional differences of premetamorphic textures.

Schmidt ${ }^{8}$ attempted to explain metamorphic differentiation purely on mechanical grounds. He suggested a process of tectonic unmixing similar to that found in rolled wrought iron, which is partially unmixed during deformation into layers of relatively pure iron alternating with carbon-rich iron. According to him, shearing of rocks causes more ductile minerals (eg. micas and amphiboles) to concentrate in layers of intense shear, whereas less ductile minerals (eg. quartz and feldspars) tend to remain in less sheared portions of the rock.

Nicholson ${ }^{6}$ described metamorphic differentiation associated with crenulation cleavages in quartz-mica schists which showed concentrations of quartz at the crests of crenulations and development of mica-rich zones at the limbs of the crenulations. He suggested that migration of silica from areas of high strain and recrystallization of quartz at sites of minimum strain 
develop this type of metamorphic differentiation. Talbot and Hobbs ${ }^{9}$ and Gray ${ }^{3}$ also described metamorphic differentiation associated with discrete crenulation cleavages. Gray produced analytical data to support his conclusion that the discrete crenulation cleavages were solution planes and he suggested that the differentiated nature was caused by passive concentration of relatively insoluble materials, such as micas and chlorite, due to solution and removal of quartz along the cleavages.

Hyndman ${ }^{4}$ discussed the formation of quartzo-feldspathic layers parallel to schiotosity and axial surfaces of folds in a series of silt and shale beds. He proposed that the metamorphic differentiation process involves migration of some compounds (eg. to form quartz and feldspars) to lower pressure surfaces parallel to schistosity and migration of other components less of this tendency to the higher pressure sites (eg. to form mafic minerals) during metamorphism and deformation.

In this paper, metamorphic differentiation associated with crenulation cleavages in some biotite schists is described and on the basis of petrographic data, it is proposed that biotite may have nucleated and grown preferentially in $\mathrm{S}_{2}$ cleavage zones. ${ }^{5}$ It is also shown that the above described processes such as solution, recrystallization and tectonic unmixing cannot explain this differentiated feature.

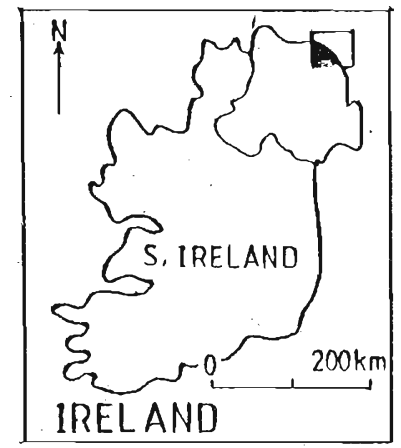

Figure 1: Location of the study area

\section{Geological setting of the study area}

The-samples examined in the present study were collected from the Dalradian rocks of north-east Antrim, Ireland (Figure 1). These rocks represent biotite grade metamorphism and have been affected by three phases of deformation. The first deformation phase $\left(\mathrm{D}_{1}\right)$ produced a slaty cleavage $\left(\mathrm{S}_{1}\right)$ and the second phase deformed these rocks intensively and produced the regional schistosity which is a discrete crenulation cleavage $\left(\mathrm{S}_{2}\right)$. The third deformation phase $\mathrm{D}_{3}$ produced small-scale folding and crenulation of $\mathrm{S}_{2}$ to form $\mathrm{S}_{3}$. 


\section{Petrography}

The examined samples are dark grey, fine grained rocks with abundant white/grey albite porphyroblasts which gave a spotted appearance to these rocks. $S_{2}$ crenulation cleavage is well developed but $S_{3}$ is weak or may be absent.

The petrographic microscope reveals that the rocks are composed of albite, muscovite, biotite, quartz, chlorite, apatite, tourmaline and ore minerals and the modal percentages of the minerals indicate that they belong to the category of pelites.

Albite : albite porphyroblasts (best seen under a microscope) are abundant in the studied rocks. A characteristic feature of the albite porphyroblast is that they contain numerous trails of inclusions which define various microstructures including $S_{2}$ and $S_{3}$ crenulations. In some specimens, albite porphyroblasts are reversely zoned at the rim. A much larger area which included north-east Antrim was studied and the age relationships of albite porphyroblast growth established. The albite porphyroblast grew during two static periods following $\mathrm{D}_{2}$ and $\mathrm{D}_{3}$ phases of deformation. ${ }^{5}$

Biotite : Two types of biotite crystals occur: fabric-forming type and slightly larger crystals (microporphyroblasts). The fabric-forming type crystals are dimensionally oriented parallel to $\mathrm{S}_{1}$ and $\mathrm{S}_{2}$ cleavages but they are

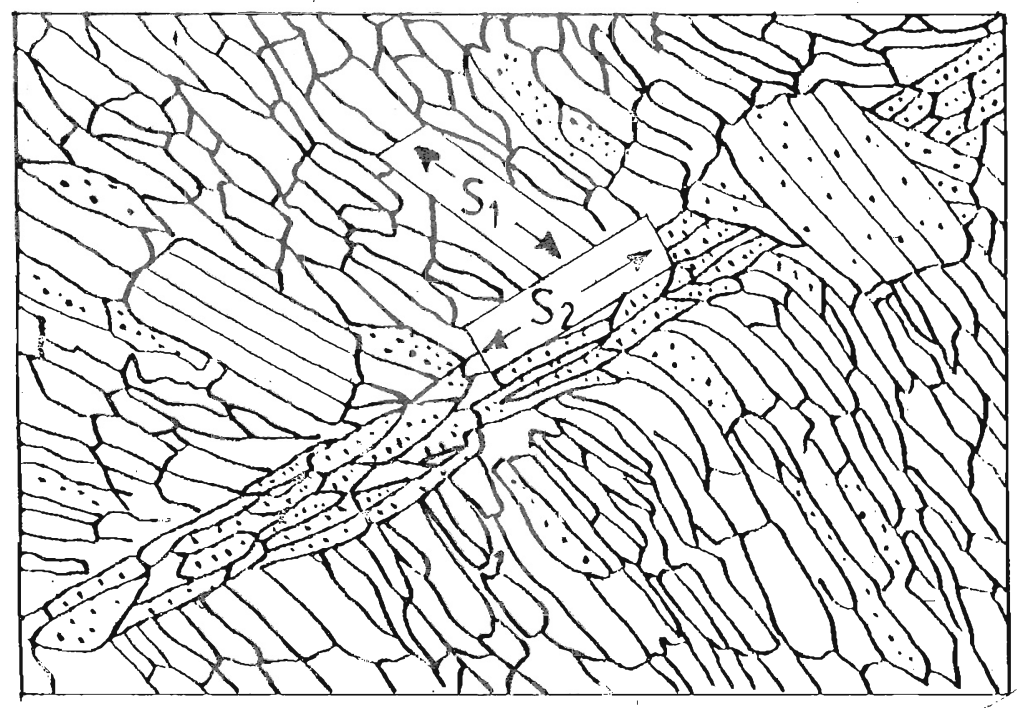

Figure 2 : Concentration of biotite crystals (stippled) along $\mathrm{S}_{2}$ cleavage zone and predominance of muscovite crystals (unshaded) outside $\mathrm{S}_{2}$ cleavage zone. Diagramatically redrawn from a microphotograph. 
characteristically concentrated along $\mathrm{S}_{2}$ cleavage zones and define biotiterich domains in the rock. The areas between $\mathrm{S}_{2}$ cleavage zones are composed mainly of muscovite and they form the biotite-poor domains (Figure 2). Fabric-forming biotite crystals are highly strained and they are curved at the junction between $S_{1}$ and $S_{2}$ cleavages indicating either rotation of the crystals during the development of $\mathrm{S}_{2}$ or Syn $\mathrm{D}_{2}$ formation of biotite crystals. Some microporphyroblasts are dimensionally aligned parallel to $S_{1}$ and $S_{2}$ but others are randomly oriented across $S_{2}$ cleavage. Biotite microporphyroblasts are strain free or only slightly strained. On the basis of texture and optical character it is inferred that biotite has grown mainly during syn $\mathrm{D}_{2}$ to post $\mathrm{D}_{2}$ period although an extended pre- $\mathrm{D}_{2}$ age cannot be ruled out.

Muscovite : muscovite crystals also occur in two forms and they are mainly confined to biotite-poor domains. Fabric-forming crystals and most microporphyroblasts are dimensionally aligned parallel to $S_{1}$. Some microporphyroblasts are dimensionally oriented across $S_{1}$. Both types of crystals may be intergrown with biotite. Textural study reveals that muscovite continued to crystallize from earliest to late stage development of the rocks.

Chlorite : primary chlorite is generally absent in the rocks studied. However, when primary chlorite is present, it occurs as dimensionally aligned crystals or the crystals may be clustered together.

Quartz : The specimens described in this study contain little or no quartz. Therefore, the biotite-rich domains as well as the biotite-poor domains are poor in quartz.

\section{Discussion}

The petrographic study reveals that the rocks studied have been differentiated, on a microscopic scale, into biotite-rich and biotite-poor domains and the biotite-rich domains coincide with $\mathrm{S}_{2}$ cleavage zones while the biotite-poor domains lie between them. Both types of domains contain little or no quartz. Also, albite which occurs as porphyroblasts show no definite spatial relationship with respect to the two domains. In this respect, the above described segregation differs from the commonly reported differentiation associated with crenulation cleavage (Figure 3). 


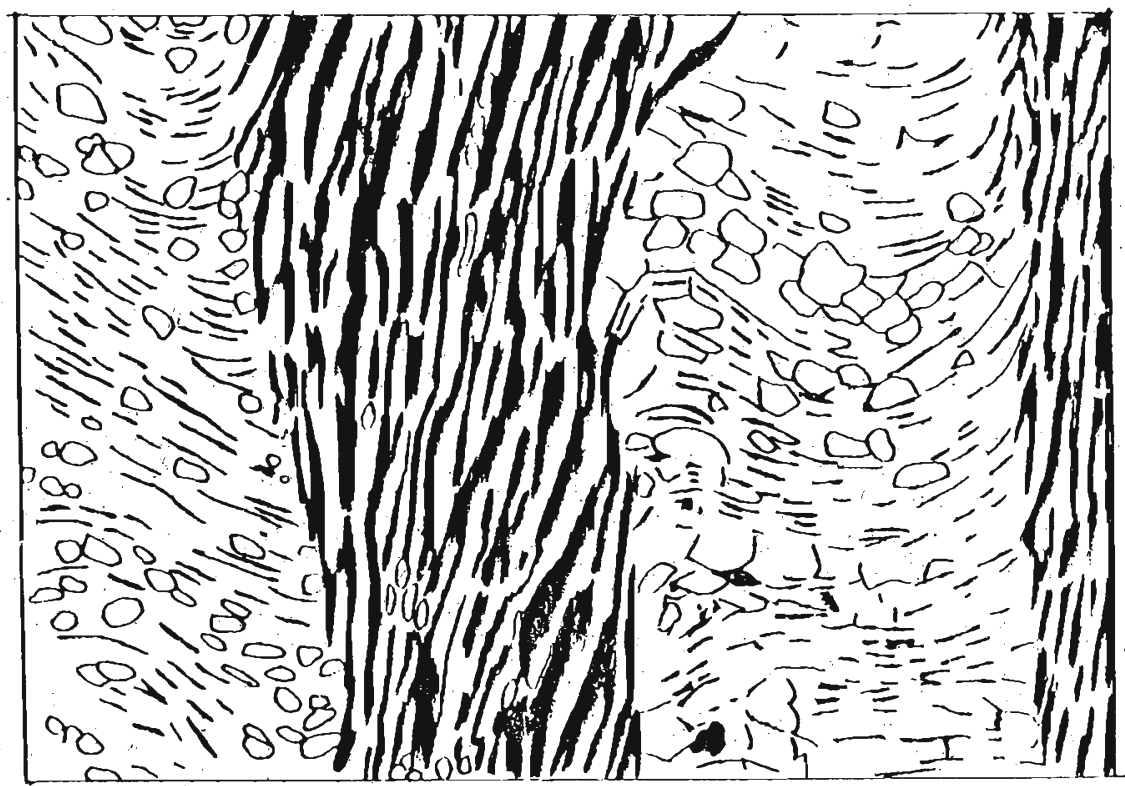

Figure 3 : Differentiation associated with crenulation cleavage. Note the dominance of quartz and feldspar (subrounded to polygonal grains) in the biotite-poor domains. Biotite-black, muscovite - blank (After. De Sitter, L. U. (1964). Structural geology, McGraw Hill).

Schmidt's ${ }^{8}$ tectonic unmixing model cannot be used to account for the observed textural and mineralogical feature because the minerals involved are mainly biotite and muscovite micas which are considered to have similar mechanical properties. Nicholson ${ }^{6}$ and Gray $^{3}$. considered that the segregation associated with crenulation cleavage was formed by selective solution and removal of silica resulting in the concentration of minerals such as chlorite, micas and amphiboles. However, there is no petrographic evidence in the studied rocks for selective solution and recrystallization of silica. Hyndman's ${ }^{4}$ model explains the contrasted mineral banding formed by quartz and feldspars on one hand and mafic minerals on the other hand but the model fails to explain adequately the observed segregation involving mainly biotite and muscovite micas.

There is no convincing textural evidence in the rocks indicating the nature of the biotite forming reaction. However, on the basis of mineralogy of the rocks and general absence of primary chloride in them, it is suggested that the biotite producing reaction is of the form,

$$
\text { muscovite }_{1}+\text { chlorite } \rightarrow \text { biotite }+ \text { muscovite }_{2}+\text { quartz }+\mathrm{H}_{2} \mathrm{O}
$$

Therefore, if the biotite producing phases were segregated along the $\mathrm{S}_{2}$ cleavage zones due to any one or more of the above discussed mechanical or chemical processes, then the growth of biotite would have produced the 
observed differentiation. However, this explanation seems to be unlikely since chlorite-bearing, biotite-free rare rocks do not show any segregation of chlorite and muscovite along the $\mathrm{S}_{2}$ cleavages.

To explain the differentiation, it is suggested on the basis of petrographic evidence that biotite is preferentially nucleated and grown in $\mathrm{S}_{2}$ cleavage zones where the phyllosilicates have their highest interval strain energy. Ease of nucleation and diffusion of biotite forming components towards the nuclei in the highly strained regions, reduce the probability of nucleation of biotite in other regions. As the nucleation and growth of iotite proceed, these regions become separated from the other regions.

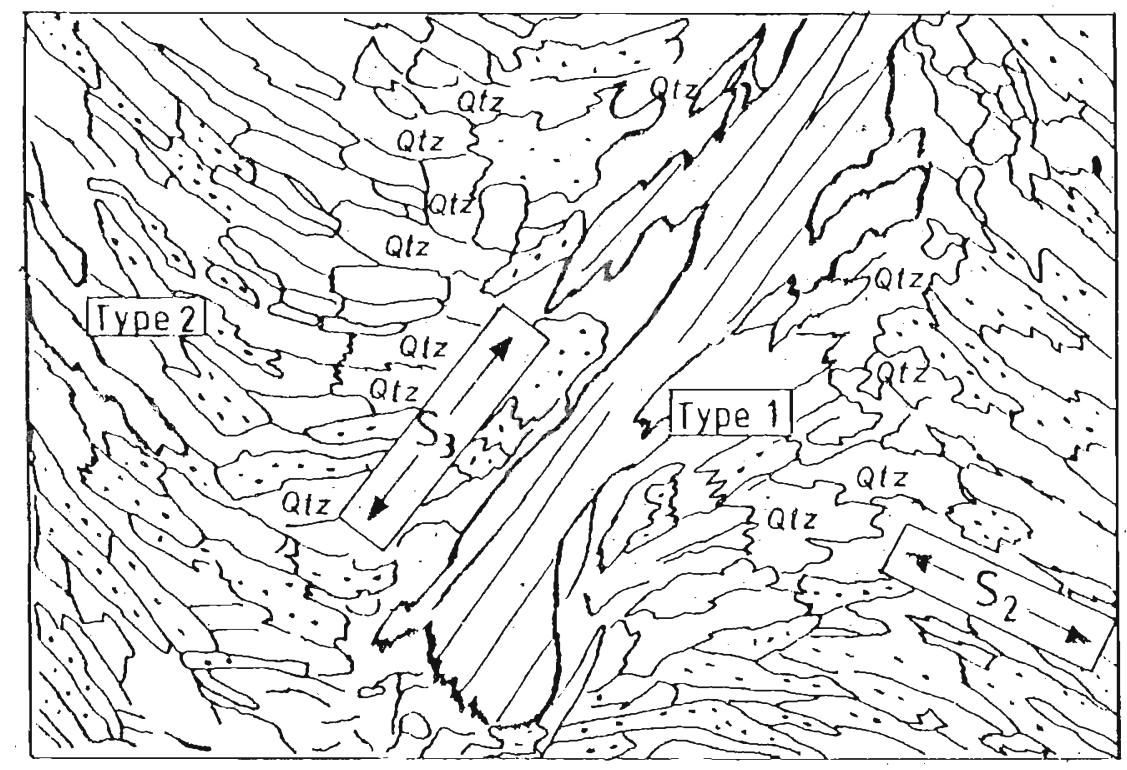

Figure 4: Large kyanite crystals (Type 1) formed along $\mathrm{S}_{3}$ cleavage zone and smaller (Type 2) kyanite crystals formed outside $S_{3}$ cleavage zone. Biotite stippled, muscovite-unshaded, quartz marked as qtz. (Redrawn from Fig. 2 of Bramwell, 1985).

Recently, Bramwell ${ }^{1}$ has described concentration of kyanite crystals in $\mathrm{S}_{3}$ cleavage zones in some pelitic rocks from Switzerland (Figure 4). The kyanite crystals in the $\mathrm{S}_{3}$ zones are compositionally zoned with respect to $\mathrm{Fe}_{2} \mathrm{O}_{3}$. He has used textural and analytical data to show that kyanite first nucleated in the $\mathrm{S}_{3}$ zones and later in the regions outside these zones. Bramwell suggested that the differentiation was produced by preferred nucleation and growth of kyanite crystals in the $S_{3}$ zones. Thus preferred nucleation and growth of minerals in highly strained regions may be an important process causing differentiation. 


\section{Acknowledgements}

The author is very grateful to Dr. K. A. Jores of the Department of Geology, Queen's University of Belfast, for thought provoking discussions on the above subject. The author wishes to thank Mrs. J. Wijesekera for the preparation of the figures, ar: $\mathrm{Mr}$. K. Dunuhappawa for typing the manuscript.

\section{References}

1. BRAMWELL, M. G. (1985). Mineralog. Mag. 49: 59-64.

2. ESKOLA, P. (1932) Bull. Comm.Geol. Finl. 97: 68.

3. GRAY, D. R. (1977) Lithos, 10: 89-101.

4. HYNDMAN, D. W. (1972) Petrology of igneous and metamorpbic rocks,, McGrawHill Book Company.

5. MATHAVAN, V. (1984). A textural and chemical study of some Dalradian albite schists. Thesis. Queen's University of Belfast.

6. NICHOLSON, R. (1966) Metamorphic differentiation in crenulated schists, Nature $209: 68-69$.

7. RAMBERG, H. (1952) Origin of metamorphic and metasomatic rocks, Univ. Chicago Press.

8. SCHMIDT, W. (1932) Tektonik und Verformungslehre. Barnstraeger, Berlin.

9. TALBOT, J. L. and HOBBS, B. E. (1968). J. Geol. 76: 581-587. 